\title{
ApresentaçÃo
}

\section{Personagem, a essência da narrativa}

M ais de três décadas dedicadas ao ensino na Escrita Criativa na PUCRS me levaram a consolidar uma ideia: os estudantes têm certa dificuldade em entender que a personagem é o verdadeiro motor da narrativa. Muitos chegam pensando que uma "boa história" - ainda não atinei o que isso significa - é suficiente para despertar o interesse do leitor. Arrastado pela história, ele irá compor a personagem que viverá todas as peripécias.

Não digo que trabalhar dessa forma é uma decisão catastrófica. É possível, até, que a narrativa seja satisfatória ao final, mas de certeza significou reescrituras, retoques, desânimos, idas e vindas, e o resultado pode ser considerado um milagre.

Por essas razões, o primeiro item das minhas aulas é dedicado à personagem. Meu alunos criam, cada qual, uma personagem com a qual irão viver por um semestre. Queixam-se, às vezes, que é muito tempo para dedicar "apenas" a uma personagem, mas procuro neutralizar o argumento com uma pergunta: "E então, já pensaram na situação do romancista, que vive vários anos com uma única personagem?" Isso, em geral, é suficiente para que mudem um pouco o que pensam acerca da minha proposta estratégica.

A partir da criação da personagem, eles a submetem a uma série de pequenas histórias ficcionais, para que verifiquem, por si mesmos, da consistência de sua criação. Só depois, no segundo semestre, é que eu parto para a elaboração de contos ou, conforme o caso, novelas e romances. Este é o momento em que os alunos têm o insight decisivo: é a personagem consistente que faz surgir a história. É como se soubessem sempre disso de maneira intuitiva, mas que não resultava em produções que lhes satisfizessem por completo.

O seguinte passo é constatar que é possível escrever um romance "sem história", em que a personagem é suficiente para levá-la adiante. Quando começamos a pensar em exemplos, um que surge com frequência é o Memórias póstumas de Brás Cubas; de fato, quando tentamos identificar os episódios que compõem o enredo dessa obra magistral de Machado de Assis, tudo falha. Os acontecimentos são tão ralos que temos de prestar muita atenção se quisermos reter algo na memória. O próprio Machado, no prólogo da terceira edição, refere a uma nota crítica publicada por Capistrano de Abreu, o qual perguntava: "As Memórias póstumas de Brás Cubas são um romance?" Brás, ele mesmo, é quem diz: um solteirão que expira aos sessenta e quatro anos não parece que reúna em si todos os elementos de uma tragédia. Nem tragédia, nem comédia. Nascido na elite social, faz viagens de estudos na Europa, nunca se casa, mantém alguns tolos relacionamentos sentimentais, dedica-se sem paixão à vida política e termina envolvido com a criação falhada do Emplasto Brás Cubas, panaceia destinada a curar a Humanidade. Até sua morte é patética: morre de uma banal pneumonia ao ficar exposto à chuva. Se pedirmos a um leitor de Machado para que descreva a história desse romance, poucos se lembrarão de todos os eventos, permanecendo nas grandes linhas biográficas de Brás Cubas. Mas ninguém esquece sua personalidade, nem a ironia e desencanto que existem nas suas célebres frases: Marcela amou-me durante quinze meses e onze contos de réis e, ao final, não tive filhos, não transmiti a nenhuma criatura o legado de nossa miséria.

A mesma lógica pode ser aplicada a outros romances, como Um coração singelo, de Flaubert, ou mesmo Crime e castigo, de Dostoiévski. Quanto a este último: toda a ação, toda "história" está subsumida pela mente do jovem Raskolnikóv, roída pelo remorso e pelo pavor de ser descoberto pelo duplo assassinato que cometeu. Se pensarmos bem, não há, nessa obra, grandes episódios - grandes ações - que cheguem a nos impressionar. É de Raskolnikóv de quem nos lembramos, e não de suas centenas de pequenas ações em meio a dezenas de personagens que não chegam a nos impressionar tanto quanto o protagonista.

A lista dos romances que trazem no título o nome de seus personagens centrais encheria todas as páginas deste livro: Tom Jones, Quincas Borba, Iracema, Clarissa, O avarento, Sargento Getúlio, Madame Bovary, Gabriela, cravo e canela, O grande Gatsby, Tonio Kröger Os irmãos Karamazóv, Macunaíma - e assim por diante. Em Os sofrimentos do jovem Werther, Goethe vai mais longe, 
não apenas ao anunciar que o herói se chama Werther, mas também que a história gira em torno de seus sofrimentos. Tudo isso significa alguma coisa, não é mesmo?

Se você leu um ótimo romance há dez anos, logo recordará, com força e vivacidade, do personagem central e do drama por ele vivido, mas irá amaldiçoar sua própria memória, que não consegue lembrar-se com agilidade dos eventos. Deixe a memória em paz e agradeça-lhe, porque ela gravou o que de fato interessa. Por outro lado, tenho certeza de que você começou a ler vários romances que abandonou depois de vinte páginas, e uma das causas deve ser a desconfiança. "Não acredito em nada disso que estou lendo, nada faz sentido". Mas alto lá. Não é do romance que você duvida, é do personagem que não convence.

É o personagem, quando bem construído, que dá sentido a tudo que acontece na história. O que pretendo dizer com isso? A narrativa deve convencer o leitor de que tudo o que ali está é porque o personagem, pelo simples fato de existir, faz com que as coisas aconteçam. Não, o personagem não tem poderes mágicos ou de super-heróis. No entanto, é como se ele atraísse os acontecimentos narrados. Ou seja, os eventos de uma história estão enraizados no personagem, inclusive os fatos incontroláveis, como um raio que destrói uma casa ou a morte de um potentado na China, para pegarmos a ideia de Eça de Queirós na novela $O$ mandarim. Soa estranho, não? Mais parece um ensinamento esotérico. Mas não é.

Avançando para os dias de hoje, percebo que os jovens ficcionistas - muitos deles meus ex-alunos ${ }^{1}$, por isso os conheço bem - preferem incidir na personagem toda sua atenção, fazendo depender dela o boa realização de suas novelas. E o fazem com êxito reconhecido pelo público, pela crítica, pelos prêmios e suas publicações no Exterior: sinal de que estão certos na escolha desse modo de encarar suas narrativas.

Este número tem a intenção de servir de discussão de diversos aspectos que envolvem a personagem, mas não apenas sob a visada crítico-teórica, mas também privilegia a criação, o que explica uma parte que abre espaço para textos ficcionais. É possível que esta seja uma das primeiras obras que tenham esse duplo caráter: o de pensar sobre um item da narrativa de ficção e, ao mesmo tempo, trazer textos criativos que servirão de exemplo e comprovação do momento reflexivo.

Como toda obra coletiva, quem fará a seleção é o leitor.

Por isso, você está com a palavra.

\footnotetext{
1 Amilcar Bettega, Carol Bensimon, Cíntia Moscovich, Daniel Galera, Luisa Geisler, Michel Laub, Paulo Scott, dentre outros de igual competência.
} 